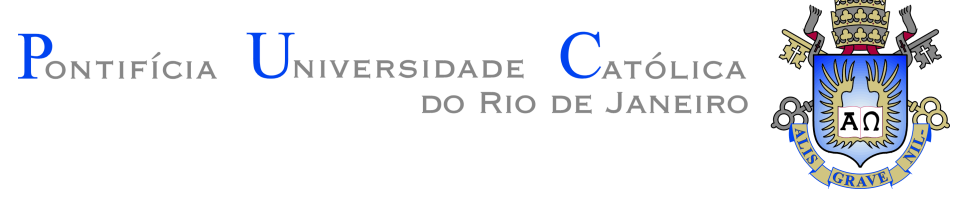

Caterina Soto Vieira

Rent-sharing, gender wage inequality and female-led firms

Dissertação de Mestrado

Dissertation presented to the Programa de Pós-graduação em Economia da PUC-Rio in partial fulfillment of the requirements for the degree of Mestre em Economia .

Advisor : Prof. Claudio Ferraz

Co-advisor: Prof. Gabriel Ulyssea 


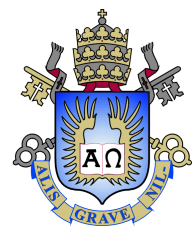

Caterina Soto Vieira

\section{Rent-sharing, gender wage inequality and female-led firms}

Dissertation presented to the Programa de Pós-graduação em Economia da PUC-Rio in partial fulfillment of the requirements for the degree of Mestre em Economia. Approved by the undersigned Examination Committee.

Prof. Claudio Ferraz

Advisor

Departamento de Economia - PUC-Rio

Prof. Gabriel Ulyssea

Co-advisor

Departamento de Economia da PUC-Rio - University of Oxford

Prof. Gustavo Gonzaga

Departamento de Economia - PUC-Rio

Prof. Cecília Machado

Fundação Getúlio Vargas - EPGE

Rio de Janeiro, March the 26th, 2019 
All rights reserved.

\section{Caterina Soto Vieira}

B.A. in Economics, University of Sao Paulo (USP-SP), 2016.

Bibliographic data

Soto Vieira, Caterina

Rent-sharing, gender wage inequality and female-led firms / Caterina Soto Vieira; advisor: Claudio Ferraz; co-advisor: Gabriel Ulyssea. - Rio de janeiro: PUC-Rio, Departamento de Economia , 2019.

v., 52 f: il. color. ; $30 \mathrm{~cm}$

Dissertação (mestrado) - Pontifícia Universidade Católica do Rio de Janeiro, Departamento de Economia .

Inclui bibliografia

1. Economia - Teses. 2. Economia do Trabalho - Teses. 3. Firmas;. 4. Rent-sharing;. 5. Desigualdade salarial;. 6. Choques de demanda;. 7. Gap de gênero;. 8. Firmas chefiadas por mulheres.. I. Ferraz, Claudio. II. Ulyssea, Gabriel. III. Pontifícia Universidade Católica do Rio de Janeiro. Departamento de Economia . IV. Título. 


\section{Acknowledgments}

First, I would like to thank my advisors Prof. Claudio Ferraz and Prof. Gabriel Ulyssea for guidance and rich contribution to this research. I am also extremely grateful for their support and encouragement during this period.

I wish to thank Prof. Gustavo Gonzaga granting me access to the RAIS and Dimitri Szerman for sharing his data from ComprasNet. This research would not have been possible without their help.

I am thankful to my family and friends for the support and understanding. I thank Lucas for everything.

Financial support from CNPq and PUC-Rio is gratefully acknowledged. 


\section{Abstract}

Soto Vieira, Caterina; Ferraz, Claudio (Advisor); Ulyssea, Gabriel (Co-Advisor). Rent-sharing, gender wage inequality and female-led firms. Rio de Janeiro, 2019. 52p. Dissertação de mestrado - Departamento de Economia , Pontifícia Universidade Católica do Rio de Janeiro.

Gender wage inequality has been widely studied and many explanations have been advanced in the literature. There is growing evidence that firms play an important role in explaining this inequality. In this paper, I make use of a unique setting with exogenous demand shocks to firms to identify if there is evidence of rent-sharing by firms and whether it differs between male and female workers. Controlling for worker quality, I find that increases in the value of the demand shock per worker do not lead to increases in wages. Demand shocks do not have effects on neither male nor female wages. Furthermore, I use a new dataset containing information on gender of firm's owner and I examine if female and male-led firms behave differently towards their employees. I find no evidence of differential rent-sharing through the structure of the firms' ownership.

\section{Keywords}

Firms; Rent-sharing; Wage inequality; Demand shocks; Gender gap; Female-led firms. 


\section{Resumo}

Soto Vieira, Caterina; Ferraz, Claudio; Ulyssea, Gabriel. Rentsharing, desigualdade salarial de gênero e firmas chefiadas por mulheres.. Rio de Janeiro, 2019. 52p. Dissertação de Mestrado

- Departamento de Economia, Pontifícia Universidade Católica do Rio de Janeiro.

A desigualdade salarial de gênero tem sido amplamente estudada e há muitas explicações. Há evidências crescentes de que as empresas desempenham um papel importante na explicação dessa desigualdade. Neste artigo, utilizo um ambiente único onde firmas sofrem choques de demanda exógenos, a fim de identificar se há evidência de rent-sharing pelas empresas e se o efeito difere entre trabalhadores homens e mulheres. Controlando pela qualidade dos trabalhadores, encontro que um aumento no valor do choque de demanda não leva a aumentos salariais. Os choques de demanda não afetam os salários de homens nem de mulheres e portanto, tampouco afeta a desigualdade salarial de gênero. Além disso, uso um novo conjunto de dados que contém informações sobre o gênero do dono da empresa e examino se as empresas lideradas por mulheres e por homens se comportam de maneira diferente em relação a seus empregados. Não encontro nenhuma evidência de que firmas lideradas por homens ou mulheres diferem com relação a rent-sharing.

\section{Palavras-chave}

Firmas; Rent-sharing; Desigualdade salarial; Choques de demanda; Gap de gênero; Firmas chefiadas por mulheres. 


\section{Table of contents}

1 Introduction $\quad 10$

2 Data $\quad 13$

2.1 Institutional Background 13

2.2 Data 14

$3 \quad$ Empirical Strategy 17

4 Results $\quad 21$

4.1 Main results 21

4.2 Rent sharing and market power 22

4.3 Testing rent-sharing by skill and firm size 24

5 Conclusions $\quad 25$ 


\section{List of tables}

Table $1 \quad$ Summary statistics at the firm level 31

Table 2 Summary statistics: worker characteristics 32

Table 3 Balance table: winners vs runner ups 33

Table 4 Correlation between instrument and pre-determined variables 34

Table $5 \quad$ Effect of demand shock on hourly wages of stayers 35

Table $6 \quad$ Effect of demand shocks on wages by gender (IV) 36

Table $7 \quad$ Effect of demand shocks on wages by firm type (IV) 37

Table $8 \quad$ Effect of demand shocks on intrafirm gender gap (IV) 38

$\begin{array}{lll}\text { Table } 9 & \text { First stage } & 39\end{array}$

Table 10 Effect of demand shock on mean wages of stayers by market share (IV) 40

Table 11 Effect of demand shocks on wages by gender and market share (IV) 41

Table 12 Effect of demand shock on mean wages of stayers by education group (IV)

Table 13 Effect of demand shocks on wages by gender and education group (IV)

Table 14 Effect of demand shocks on wages by firm type and education (IV)

Table 15 Effect of demand shock on mean wages of stayers by firm size (IV)

Table 16 Effect of demand shocks on wages by gender and firm size (IV)

Table 17 Effect of demand shocks on wages by firm type and size (IV)

Table 18 Summary statistics: firm characteristics

Table 20 Effect of demand shocks on different measures of wages (IV)

Table 21 Effect of demand shocks on next year wages

Table 22 Effect of demand shock on mean wages of stayers by market share (hires) 


\section{List of Abreviations}

RAIS - Registro Anual de Informação Social

HHI - Herfindahl-Hirschman Index

ISIC - International Standard Industrial Classification

CNAE - Classificação Nacional de Atividades Econômicas

CBO - Classificação Brasileira de Ocupações 


\section{Introduction}

Even though competitive labor market models predict firms take wages as given, there is mounting empirical evidence on firms' power to set wages and to contribute to wage inequality (Card et al., 2018; Song et al., 2015; Barth et al., 2014). One way firms can contribute to earnings inequality is through rent-sharing. The relationship between worker compensation and changes in firm productivity has been widely explored (Card et al., 2013; Van Reenen, 1996; Card et al., 2016; Macis and Schivardi, 2016; Kline et al., 2018).

Brazil exhibits pervasive levels of inequality, with a Gini Coefficient of 0.593 in 2001. According to Ferreira et al. (2004) it has one of the highest levels of income inequality in the world. Recent studies investigated the role firms play to the recent decrease of wage inequality and have found that firms account for 45 percent of the decrease in the variance of log earnings between 1996 and 2012 (Alvarez et al., 2018; Lopes de Melo, 2018). However, there are few studies about rent-sharing contributing to wage inequality in Brazil; empirical evidence is scarce and sometimes conflicting (Martins and Esteves, 2006; Menezes-Filho et al., 2008).

Gender wage gap persists in many countries and many explanations have been advanced about it (Goldin, 2006, 2014; Goldin and Katz, 2016; Goldin et al., 2017; Blau and Kahn, 2017, 2003). Brazil also exhibits high levels of gender wage disparities, which have stagnated despite significant advances in social equality regarding educational attainment and female labor supply (Madalozzo, 2010; Fraga et al., 2017; Salardi, 2012). Rent-sharing can affect gender wage inequality if women obtain a smaller share of the surplus in comparison to men (Black and Strahan, 2001; Card et al., 2018; Nekby, 2003). Furthermore, female leadership might affect firm performance, wages and ultimately gender wage gap (Cardoso and Winter-Ebmer, 2010; Bertrand et al., 2014; Flabbi et al., 2016; Gagliarducci et al., 2015; Hardy and Kagy, 2018). Differences in wages by firm ownership might arise if female executives are better equipped at interpreting signals of productivity from female workers, for example.

In this paper I make use of a unique setting where firms face exogenous demand shocks to assess the effect of demand shocks on workers' wages, 
controlling for worker quality. These are sizable shocks with substantial effects on firms' growth, as shown by Ferraz et al. (2015). The wage response to procurement shocks is of interest for several reasons. First, Ferraz et al. (2015) show that firms exhibit a learning behavior once they win close auctions: they enter more auctions, win more contracts and win a larger share of auctions they enter. These changes in firms' behavior suggest that these auctions are profitable. Second, procurement auctions constitute firm-specific shocks, which filters out market-wide wage responses, making my estimation of rent-sharing more precise.

I use matched employer-employee data linked to data from online auctions for off-the-shelf goods procured by the Brazilian Government. These auctions have sizable contract values on average and also have special features that make it possible to categorize winning an auction as random. The empirical strategy follows Ferraz et al. (2015) and allows the comparison of firms that won government contracts with firms that compete in these auctions, but won less. Employer-employee data has gender information at the worker level and this permits the study of the heterogeneous effects of demand shocks on wages of female and male workers.

I find that demand shocks coming from procurement auctions have no impact on workers' wages. Point estimates of rent-sharing elasticities are very small and are not statistically significant. I separate the analysis between male and female wages and find no evidence of gender differential rent-sharing by firms. Also, there are not significant increases on the within-firm gender gap, calculated as the difference between the mean wage of male and female workers divided by the mean wage of men.

With a new dataset containing the gender of all firm owners in my sample, I address the question of whether female-led and male-led firms behave differently towards their employees. The estimation results by female-owned, male-owned, and mixed-gender (equal share of male and female owners) firms suggest that these types of firms do not share rents with their workers overall and also don't have different rent-sharing policies.

In addition to the papers cited above, my paper relates to the following strands of literature. First, I contribute to the broad rent-sharing literature, given that the vast majority of existing studies use fluctuations in firm's productivity or rents which can be related to market-wide fluctuations (Card et al., 2013; Macis and Schivardi, 2016; Van Reenen, 1996; Hildreth, 1998; Kline et al., 2018; Card et al., 2016; Cho, 2018; Blanchflower et al., 1996). I estimate rent-sharing in an environment with firm-specific exogenous demand shocks. Thus, my paper relates closely to Kline et al. (2018) who explore how 
patent-induced shocks to productivity affect workers' wages.

My second contribution is to the literature that studies determinants of wage inequality in Brazil (Martins and Esteves, 2006; Arbache and MenezesFilho, 2000; Menezes-Filho et al., 2008; Alvarez et al., 2018; Helpman et al., 2017). Most evidence of rent-sharing is from developed countries, where workers on average have accumulated more human capital and they have more bargaining power. In Brazil, the evidence about existence of rent-sharing is conflicting and I complement this literature using a different empirical strategy to estimate it.

Thirdly, by examining how demand shocks affect intra-firm gender wage gap, I relate to the gender wage gap literature, specifically with studies that investigate the relationship between gender wage inequality and firm-specific pay policies (Card et al. (2016), Black and Strahan (2001), Goldin et al. (2017)). Finally, my paper contributes to the expanding literature on how female leadership affects outcomes of firms (Hardy and Kagy (2018), Bertrand et al. (2014), Flabbi et al. (2016), Gagliarducci et al. (2015), Cardoso and Winter-Ebmer (2010)). It relates closely to Hardy and Kagy (2018), who studied the effect of demand shocks on the gender profit gap between male and female-owned firms. Since both Cardoso and Winter-Ebmer (2010) and Flabbi et al. (2016) find effects of female leadership on wages, I examine the heterogeneous effect of demand-shocks on wages by ownership of firms.

This paper is organized as follows: the next section describes the context of the demand shocks and the data used, while section 3 explains the empirical strategy. Results are displayed in section 4 and I conclude in section 5. 


\section{Data}

\section{1}

\section{Institutional Background}

Concerned with increasing transparency and with improving the supervision of Government procurement, Brazilian federal government started making use of online procurement mechanisms (World Bank, 2004). In 2001, the Brazilian federal government successfully developed and implemented an online procurement bidding platform named ComprasNet. Almost half of all procurement for the federal government was conducted through ComprasNet, amounting to 0.7\% of Brazilian GDP in 2010. Auctions held in ComprasNet represent a large share of federal tenders and, most importantly, a substantial amount is contracted through ComprasNet.

Since 2005, federal government has been obliged to make purchases of off-the-shelf goods using ComprasNet through online reverse auctions. ${ }^{1}$ Offthe-shelf goods have very precise specifications so that these reverse auctions can be determined solely by the lowest bid. Off-the-shelf goods are usual non-complex goods or services, which can be easily and objectively defined in bidding documents. Some examples of these goods are bottled water, coffee, cleaning materials or services and pharmaceuticals. Most of procurement falls into the off-the-shelf category.

Online procurement platforms facilitate firms' participation in auctions since registration process is rather simple and objective. Besides that, most documents needed to support a firm's bid are submitted after winning an auction, which lowers participation costs for firms. From 2004 to 2010, over four million reverse auctions were held in ComprasNet and 42,398 firms placed bids in at least one auction. In order to participate in an auction, firms register as vendors, providing information about which goods they can supply, and the system shows them compatible procurement auctions.

\footnotetext{
${ }^{1}$ Reverse auction is a method used for procurement of off-the-shelf goods, regardless of their value. In a reverse auction, following advertisement of the auction, bidders submit an initial price proposal in a sealed envelope. During a public session, bidders lower their bids until the lowest possible price is reached, within stipulated time limits.
} 
Reverse auctions have a special feature: they end at sudden, within stipulated time limits. That means that neither firms nor the auctioneer know when will the auction end. Szerman (2012) rationalize the key elements of bidding behavior in auctions with random ending time in a theoretical model. Empirical evidence suggests that under random ending rules: i) bidders wait until the end phase of the auction to bid; ii) most auctions resolve early; and iii) bid increments are typically small. The random component of such auctions arises when firms adopt an incremental bidding strategy at the end phase (Ferraz et al., 2015).

Another important feature of reverse auctions in ComprasNet is that firms must manually change their bids each time they want to increase them in a given auction. The friction generated by the absence of an automatic bid replacement system provides reassurance that winning an auction is close to random.

If two firms are competing to win an auction without knowing when the auction ends, which firm wins the auction can be considered random. These auctions are called close auctions. Thus, limits are stipulated to define what is considered to be a close auction: one which at least two firms are still bidding within the last 30 seconds of its end and the difference between winning and losing bid is less than $0.05 \%$ of the second place bid. In Chapter 3, I will explain in detail how I use close auctions for my identification strategy.

\section{2 \\ Data}

I use two main sources of data: ComprasNet and RAIS. ComprasNet provides data on more than 4.2 million reverse auctions held between 2004 and 2010. It provides auction-level information in which firms participated, their bids, the ending time of the auction, and their reservation prices. ${ }^{2}$ Information about all bids placed by each firm in a given auction and timing of the bids is sufficient to categorize an auction's strategy and define it as a close auction or not. I have information about all the auctions a firm has participated in, which they have won and whether it was a close auction.

ComprasNet also provides specific information of vendors, as the number of owners per firms and their names. Using a correspondence between name and gender, I was able to assign gender to each partner of these firms. I exclude from my sample firms with only legal entities owners (less than $3 \%$ ), since it does not provide me information on gender. A firm was defined as female-led if

\footnotetext{
${ }^{2}$ The reservation price is a baseline value obtained by the average of three quotes obtained from market research, if bids are higher than the reservation price, the auction is cancelled.
} 
more than $50 \%$ of its owners were female, male-led as those having more than half male owners, and mixed-gender as those with the same share of male and female owners, an approach similar to Cardoso and Winter-Ebmer (2010).

I include in my final estimation sample only firms with at least one owner who is an individual. Table 1 shows information at firm level about the owners. Firms have on average approximately two owners and there are more male owners than female owners. My final sample contains 41,002 firms that had information about owners and had at least one person owner. Female-led firms represent $16.1 \%$ of my sample, whereas male-led firms represent $47.5 \%$, and mixed-gender firms represent the remaining $36.4 \%$.

Data from ComprasNet is complemented with internal data from the Ministry of Planning, Budget, and Administration to obtain additional information on lots and bidders. Lots are typically some indivisible quantity of an off-the-shelf good and are the unit measure for the goods procured in an auction. This data provides more information about the nature of the goods procured and their product category at a very thin level. Goods that are more frequently procured are books, medical and veterinary equipment, and laboratory equipment.

Secondly, I use matched employer-employee data from Relação Anual de Informações Sociais (RAIS) from 2003 to 2011. Data from RAIS is collected annually by the Ministry of Labor and gathers information about all formal firms and workers. It contains data on wages, gender, education, occupation, hours worked, tenure, and age of every employee. RAIS also has information about the firms such as industry sector as defined by International Standard Industrial Classification (ISIC). Data from ComprasNet and RAIS were merged using firms' tax identification number.

The sample considers workers between 18 and 70 years old with positive earnings, while those with contracts less than three months longer are not considered. A second important issue that impacts the size of the sample is that out of 42,398 firms, only 31,126 are found in RAIS in any year. The other firms are in another administrative dataset, RAIS negativa, and do not have employees therefore are also not included in my final estimation sample. I also restrict the sample to firms that have at least one male and one female worker.

RAIS presents two measures of earnings, the average monthly wage of workers considering all months and the wage in December. Considering most procurement auctions are issued by the end of the year my preferred measure of earnings is wage in December ${ }^{3}$, because it measures precisely the short-run effect of the demand shock. Also, all my measures of earnings used in the

\footnotetext{
${ }^{3}$ Approximately $41 \%$ of auctions end between October and December.
} 
regressions are hourly wages to make sure that the effect is not capturing an increase in hours worked instead of increases in wages effectively. Firms are not obliged to declare any bonus as wages in RAIS, therefore it is possible that my measure of rent-sharing does not capture entirely profits captured by workers.

Table 2 presents some summary statistics for a yearly unbalanced panel of firms from 2004 to 2010. Column 1 shows that the average size of the firms in the sample is 17 employees, on average firms hire 9 workers per year and lay off 7 workers. On average, firms have $31 \%$ female workers and male workers earn higher wages than female workers. Mixed-gender firms look more like the average firm of the sample, while female-owned are considerably smaller firms than the other types of firms. They relatively employ more women, but pay lower wages to both male and female workers.

In column 5 , I test the means of these variables for female-owned and male owned firms with a regression that controls both for the number of workers of a firm and an industry sector variable (CNAE 4 digit). These firms are statistically different in variables related to wages, even when we account for firm size and industry. They are not different when it comes to variables related to employment, such as hires and layoffs controlling for firm size. Tables 18 and 19 in the Appendix show summary statistics for auction related variables and some other firm characteristics. The average demand shock, as shown in table 19, is considerably high, especially when compared with the average monthly wage bill. Taking into account that about $27.6 \%$ of the firms in my sample win at least one auction in the sample period, the average shock conditional on winning a contract is about $\mathrm{R} \$ 2.4$ million. 


\section{3 \\ Empirical Strategy}

We are interested in assessing what is the effect of the demand shock coming from procurement auctions on wages, so we could estimate the following model:

$$
Y_{i t}=\beta_{0}+\beta_{1} G_{i t}+\alpha_{i}+\delta_{t}+\kappa_{i t}+\epsilon_{i t}
$$

where $G_{i t}$ is the demand shock from government procurement auctions in firm $i$ in year $t$ measured as the value of contracts won, $Y_{i t}$ is $\log$ of the mean wage of incumbent workers in December in firm $i$.

Firm fixed effects are given by $\alpha, \delta$ are year fixed effects, $\kappa$ are controls for characteristics of the firms that change over time. The demand shock $G_{i t}$ is given by the amount won in procurement auctions by a firm in a given year. Therefore, $\beta_{1}$ would be the effect of the demand shock on mean wage. However, coefficient $\beta_{1}$ will be biased if unobservable characteristics of firms are related to the winning procurement auctions. For example, if any unobservable characteristic of the firm is related both to wage-setting decisions of the firm and to the amount won in auctions the estimation of the coefficient of interest will be biased.

To overcome this, I follow the empirical strategy of Ferraz et al. (2015) taking advantage of the design of the auctions to construct exogenous demand shocks. These exogenous shocks are used as an instrument to estimate the effects of winning government contracts. The empirical strategy is based on the existence of auctions in which firms use incremental bidding strategy towards the end of auction. These firms are competing to win these auctions and the sudden ending of auctions generates randomization in relation to which firm wins. Thus, limits are stipulated to define what is considered to be a close auction: one which at least two firms are still bidding within the last 30 seconds of its end and the difference between winning and losing bid is less than $0.05 \%$ of the second place bid. Therefore, I use the share of value won in close auctions as an instrument and estimate the following model by 2SLS: 


$$
\begin{aligned}
Y_{i t} & =\beta_{0}+\beta_{1} \hat{G}_{i t}+\alpha_{i}+\delta_{t}+\kappa_{i t}+\epsilon_{i t} \\
G_{i t} & =\gamma_{0}+\gamma_{1} Z_{i t}+\eta_{i}+\lambda_{t}+\xi_{i t}+u_{i t}
\end{aligned}
$$

where $Z_{i t}$ is the share of the value won in close auctions participated $\alpha$ and $\eta$ are firm fixed effects, $\delta$ and $\lambda$ are year fixed effects. The share of the value won is calculated as the ratio of the value a given firm won in all close auctions it has participated in period $t$ to the sum of the values of the close auctions it has participated in the same period ${ }^{1} . \xi$ and $\kappa$ are controls for firms' characteristics and $\beta_{1}$ is the causal effect of the demand shock of procurement auctions on wages conditional on participation.

I use wages in December of workers to calculate the mean wage for each firm and I consider only the workers who were already employed by the firm the year before the shock, so that the effect can be interpreted as within-firm changes in wages over time due to the demand shocks. The literature usually refers to these workers as stayers and this is an attempt to control for variation in worker quality.

My dependent variables are at the firm level and to assess if there is evidence of differential rent sharing between male and female workers I estimate different regressions, one with $Y_{i t}$ as the mean December wage of stayer male workers and the other as mean December wage of stayer female workers. To test if demand shocks affect gender wage gap I use a measure of intra-firm gender gap calculated as difference between mean wages of male and female workers divided by mean wage of male workers. This gives me the percentage difference between male and female wages.

I include controls for average worker age, average worker tenure, proportion of high skilled workers and mean occupation ranking and maximum occupation ranking, all disaggregated by gender. The occupation control is calculated using all workers in RAIS of 2004 to rank occupations in wage percentiles by their average income weighted by labor supply.

I am also interested in whether female-led firms, male-led firms and mixed gender firms have different rent-sharing policies towards their employees. In that case, I estimate the following model by 2SLS:

$$
\begin{aligned}
& Y_{i t}=\beta_{0}+\beta_{1} \hat{G}_{i t}+\beta_{2} \hat{G}_{i t} * \text { Female-led }+\beta_{3} \hat{G}_{i t} * \text { Male-led }+\alpha_{i}+\delta_{t}+\kappa_{i t}+\epsilon_{i t} \\
& G_{i t}=\gamma_{0}+\gamma_{1} Z_{i t}+\gamma_{2} Z_{i t} * \text { Female-led }+\gamma_{3} Z_{i t} * \text { Male-led }+\eta_{i}+\lambda_{t}+\xi_{i t}+u_{i t} \\
& { }^{1} Z_{i t}=V_{i t}^{\text {winclose }} /\left(V_{i t}^{\text {winclose }}+V_{i t}^{\text {loseclose }}\right)
\end{aligned}
$$


where Male-led and Female-led are dummy variables and the $\beta_{1}$ shows the effect of the demand shock for mixed-gender firms. I use the share of female partners to classify firms between these types and mixed gender firms have equal number of male and female partners. The interactions of the demand shock with the dummies of firm type are instrumented by the interactions of the exogenous variable $Z_{i t}$ with the dummies.

I use the definition of close auction which at least two firms are still bidding within the last 30 seconds of the auction ending and the difference between the winning and losing bid is less than $0.05 \%$ (Ferraz et al., 2015). My identification assumption is that my instrument is exogenous not only to wages but to every unobservable characteristic of the firm related to wagesetting decisions, because of the sudden ending of the auctions. I also assume that these procurement demand shocks have no direct effect on labor supply. To test whether winning close auctions is as good as random, I test if firms who barely won close auctions have similar characteristics to those that barely lost it in Table 3. Results suggest that winners and runner ups characteristics before the year of the shock are balanced in observable dimensions relevant to wage-setting decisions.

On average, they present similar shares of female employees, mean wages, mean wages of female and male workers separately, average tenure and age of employees. Only the number of employees and the number of female employees are significantly different across the two groups at a $5 \%$ level. Winners have on average 30 employees and runner ups 24.5. This difference, while statistically significant, is not great in absolute terms (Table 3). Ferraz et al. (2015) shows that these firms are also similar in growth rates in the previous year and winning rates of previous auctions. One caveat, however, is that this is not the usual balance table: because firms participate in sometimes more than one close auction per year, they are sometimes both in the control and in the treatment groups.

To test validity of the instrument, I check whether it is correlated with past characteristics of the firms in my sample on Table 4. In column 1, I regress the share won in close auctions on firms' characteristics in the period immediately before the shock, in column 2 on firms' characteristics two years before the shock and in column 3 I show it is also not correlated with the variation of firms' characteristics. These results suggest past characteristics of the firms in my final estimation sample are not correlated with my instrument. The share of value won in close auctions is correlated only with the mean wage of female workers and the mean occupation ranking of women at $t-1$, but this is only significant at a $10 \%$ level and coefficients are really small. Regressing $Z_{t}$ 
on characteristics at $t-2$ in column 2 , correlation only appears to few variables at $10 \%$ level and with very small point estimates. Hence, exclusion restriction is satisfied and my instrument is as good as randomly assigned. 


\section{Results}

\section{1}

\section{Main results}

Table 5 presents the effect of the demand shock coming from winning procurement auctions on the mean wages of stayer workers, conditional on participation in at least one close auction in the year of the shock. All estimations include firm and year fixed effects. I include in my final estimation sample only firms that participated in at least one close auction in the year of the shock. I also consider only firms that have at least one female and one male worker. All standard errors are clustered at the firm level and the unit of observation is a firm-year pair. The average demand shock conditional on winning a contract is about $\mathrm{R} \$ 2.4$ million.

Column 1 presents the OLS estimates of the shock and column 2 the IV estimates. The results suggest that there is no evidence of rent-sharing after an auction. Not only point estimates are very small, but they are also not statistically different from zero. The IV estimates, instrumented by the exogenous variation of the share won in close auctions, are more appropriate for understanding the effect of winning an auction on wages and they also suggest no evidence of rent-sharing, when controlling for worker quality. First stage estimates are in Table 9 and they are positive and statistically significant, as expected.

Procurement auctions exhibit a cyclical component and most part of these auctions are issued by the end of the year. I also estimate these effects with other measures of mean wages and present them in Table 20, but rentsharing estimates are zero independent of the wage measure chosen. Auctions happen mostly in the end of the year and I verify whether the effect on wages appears in the year following the shock, considering wages might not respond in the very short run to the demand shock. In table 5, I test whether the demand shock affects wages in the year next to the shock, but also find no effects.

The rent-sharing literature usually finds positive elasticities and the average rent-sharing elasticity estimated in the papers that control for worker 
quality is 0.08 (see Card et al. (2018)). I must take into account, however, that these shocks are a reduced form of the entire rent of firms, which means that there might be sizable demand shocks also coming from the private sector, for example. The absence of rent-sharing in this context only shows that demand shocks coming from government purchases do not have effects on wages. Nonetheless, because my OLS estimates are smaller than the IV estimates, it is likely that shocks coming from government purchases are negatively correlated to private sector demand shocks.

All the following results are estimations using 2SLS. Table 6 suggests that the demand shock has no effect on both mean wage of male and female workers. Columns 1 and 2 show the IV estimates and even though point estimates for male workers' wages are higher they are both statistically insignificant, suggesting there isn't differential rent-sharing.

In Table 7, I show the estimated effects of the demand shock on wages, exploring heterogeneity between mixed-gender, female or male-led firms. Column 1 shows the effect on mean wage of all workers, column 2 on male workers and 3 on female workers. Overall, this table suggests that there is no evidence of rent-sharing in all types of firms. There is also no evidence of differential rent-sharing by gender in this case, considering the effect is zero for both male and female workers.

To test if demand shocks affect the gender wage gap, I use as dependent variable the intra-firm gender gap, measured by the ratio of the difference between the mean wage of male and female workers and the mean male wage. It measures the percentual gender wage difference relative to the mean male wage within a firm, but it does not control for any observable characteristics of the workers. In Table 8, the estimates show the demand shock doesn't generate any effect on the intra-firm gender gap as expected. This result agrees with evidence from Bertrand et al. (2014), where a larger share of women in higher positions within firms does not affect gender gap or wages.

\section{2}

\section{Rent sharing and market power}

In the monopsonistic model with an upward sloping short-run labor supply, when there is a demand shock a positive correlation between wages and profits appears in the short run. When the economy is hit by a positive shock, firms move up along the supply curve, and profits will rise together with employment and wages (Blanchflower et al., 1996). Indeed, empirical evidence shows that firms with higher market power share on average more of their rents than firms with low power (Black and Strahan, 2001; Bell et al., 2018). 
Benmelech et al. (2018) emphasize the role of labor market monopsonies in influencing firm wage-setting behavior. That is, monopsonist employers can exploit their market power to influence wages. Considering the relationship between market concentration and wages, I test whether firms in more concentrated labor markets share rents with their workers.

To measure labor market concentration, I use all RAIS from 2004 to 2010 to construct the Herfindahl-Hirschman Index (HHI) of firm employment at the state-sector-year level. The formula for the HHI in market $m$ and year $t$ is

$$
H H I_{m, t}=\sum_{j=1}^{J} s_{j, m, t}^{2}
$$

where $s_{j, m}$ is the market share of firm $j$ in market $m$. The market share of a firm in a given sector and state is defined as the wage bill of the firm divided by the total wage bill of that sector and state in year $t$.

I use two measures of market share: wage bill and number of hires. The first is an approximation to measure labor market share. The second is because, according to Azar et al. (2018), job openings are a better gauge of how likely searching workers are to receive a job offer. If jobs are vacated less frequently, concentration of employment is a less relevant gauge of available work and employer market power than is the concentration of vacancies among the relatively few firms who are likely to be hiring at any given time. The two measures are considerably correlated (0.71) and the estimates using both measures are quite similar, albeit the second seems to be more conservative.

The U.S. Department of Justice ${ }^{1}$ considers a market with an HHI of less than 0.15 to be a competitive marketplace, an HHI of 0.15 to 0.25 to be a moderately concentrated marketplace, and an HHI of 0.25 or greater to be a highly concentrated marketplace. The HHI takes into account the relative size distribution of the firms in a market. It approaches zero when a market is occupied by a large number of firms of relatively equal size and reaches 1 when a market is controlled by a single firm. The HHI increases both as the number of firms in the market decreases and as the disparity in size between those firms increases.

Using the same guidelines, I define a competitive labor market as one with HHI under 0.15 and concentrated labor markets as those with HHI above 0.15. Approximately $90 \%$ of the observations of my sample are from firm-years in competitive markets. I define local labor markets as state-sector-year cells, an attempt to consider that workers aren't geographically mobile on average.

${ }^{1}$ See U.S. Dep't of Justice \& Fed. Trade Comm'n, Horizontal Merger Guidelines (2010), available at http://www.justice.gov/atr/public/guidelines/hmg-2010.html. 
In Table 10, column 1 shows estimates of rent-sharing elasticities of firms that are in competitive labor markets. The point estimate is similar to that of table 5, which considers the whole sample and both are statistically equal to zero. Column 2 shows the results for firms in concentrated markets and the point estimates of the rent sharing elasticities are positive and considerably greater but they are statistically insignificant. This suggests that firms with higher market power share also do not share rents with their workers in Brazil. The analysis with my second measure of market power are quite similar to those shown here and are presented in the Appendix on table 22.

\section{3}

\section{Testing rent-sharing by skill and firm size}

In this section, I explore other potential explanations highlighted by the literature. It is plausible that rents are shared mostly with higher skilled workers, leading to differential rent-sharing in the education dimension and not gender, as rationalized by Card et al. (2018). Therefore, I test whether more educated workers receive, if any, a greater share of rents than less educated workers. I define high skilled workers as those that have completed at least high-school. Table 12 shows that there is no evidence of rent sharing to neither high skilled nor low skilled workers. The number of observations is smaller than my final estimation sample because not all firms employ both low skilled and high skilled workers.

Table 13 indicates that there isn't evidence of differential rent-sharing by gender within education groups. Even though point estimates are higher for higher skilled male workers and lower skilled female workers, all coefficients are statistically zero. There is no evidence of rent-sharing through the structure of firm ownership for each education group, as showed in Table 14.

Ferraz et al. (2015) use this setting to test whether firms that win procurement auctions grow more and one of their findings is that the effect of the demand shocks on growth rate is higher for smaller firms. Therefore, I test whether the wages of workers in firms below and above the median size are affected differently by the demand shocks in table 15. I also find that these demand shocks have no effect on wages of firms above and below the median size. Smaller firms do have a greater coefficient, but it is zero statistically. There aren't any interesting different effects separating the analysis by gender or firm ownership, as seen in Tables 16 and 17. 


\section{5}

\section{Conclusions}

This paper tests whether wages respond to demand shocks coming from procurement auctions. I complement the literature that examines rent-sharing in developing countries and I am, as far as I know, the first to analyze differential rent sharing in Brazil. Moreover, the quality and richness of the data used allied with specific features of government purchases in Brazil allows me to use firm-specific shocks with a credible identification strategy to estimate rent-sharing.

Even though procurement demand shocks are sizable, winning a government contract seems to have no effect on workers' wages. Across all specifications, I find precisely estimated parameters indicating virtually zero rentsharing. Absence of rent-sharing in Brazil is a result also found by Martins and Esteves (2006) and it might be explained by low bargaining power of Brazilian workers and weak unions.

There is no evidence of different rent-sharing between male and female workers nor high and low skilled workers. The demand shock does not impact intra-firm gender wage gap. Even though mixed gender, female and male led firms are very different in many dimensions that would suggest these firms have different wage setting policies, they do not share rents with their workers in a different way. All these firms have rent-sharing elasticities statistically equal to zero. Firm size is also not an important dimension regarding rent-sharing, neither firms above nor below the median size share rents with their workers.

I explore alternative explanations to further understand the absence of effect on wages by these demand shocks. A positive correlation between wages and rents is not a feature expected in competitive labor market models, in which wages are given and demand shocks would not affect them, only employment. There are at least three ways rents are captured by workers in the form of higher wages: incentive pay models, where risk-averse workers and firms share gains and losses, wage setting models, where there is a bargaining process between workers and firms and monopsonistic models, where demand shocks would rise both profits, wages and employment.

I test whether firms with a higher market power share profits with their workers and also find no evidence of rent-sharing in both competitive 
and concentrated markets, considering local labor markets as sector-year-state unit. Therefore, the absence of rent-sharing is more likely to be related to institutional reasons, such as low bargaining power of workers, weak unions and minimum wage. Another possible explanation is the existence of measurement error in the wage variable of RAIS, because firms are not obliged to report bonus paid to workers, only increases in wages. In that case, my results are a lower bound of rent-sharing in Brazil.

My results show government purchases do not contribute to wage inequality and to gender wage disparities. At least regarding gender discrimination, it is positive that Goverment purchases do not increase gender wage gap through rent-sharing. This is relevant for a better understanding of the Brazilian labor market and could help future analysis and implementation of policies that want to better understand and decrease inequalities. 


\section{Bibliography}

Alvarez, J., Benguria, F., Engbom, N., and Moser, C. (2018). Firms and the decline in earnings inequality in Brazil. American Economic Journal: Macroeconomics, 10(1):149-89.

Arbache, J. S. and Menezes-Filho, N. (2000). Rent-sharing in Brazil: using trade liberalization as a natural experiment. In Rio de Janeiro: Annals of the $V$ Annual Meeting of the Latin American and Caribbean Economic Association. Citeseer.

Azar, J. A., Marinescu, I., Steinbaum, M. I., and Taska, B. (2018). Concentration in U.S. labor markets: Evidence from online vacancy data. Technical report, National Bureau of Economic Research.

Barth, E., Bryson, A., Davis, J. C., and Freeman, R. (2014). It's where you work: Increases in earnings dispersion across establishments and individuals in the us. Technical report, National Bureau of Economic Research.

Bell, B., Bukowski, P., and Machin, S. (2018). Rent sharing and inclusive growth.

Benmelech, E., Bergman, N., and Kim, H. (2018). Strong employers and weak employees: How does employer concentration affect wages? Technical report, National Bureau of Economic Research.

Bertrand, M., Black, S. E., Jensen, S., and Lleras-Muney, A. (2014). Breaking the glass ceiling? the effect of board quotas on female labor market outcomes in norway. The Review of Economic Studies.

Black, S. E. and Strahan, P. E. (2001). The division of spoils: rent-sharing and discrimination in a regulated industry. American Economic Review, 91(4):814831.

Blanchflower, D. G., Oswald, A. J., and Sanfey, P. (1996). Wages, profits, and rent-sharing. The Quarterly Journal of Economics, 111(1):227-251.

Blau, F. D. and Kahn, L. M. (2003). Understanding international differences in the gender pay gap. Journal of Labor Economics, 21(1):106-144.

Blau, F. D. and Kahn, L. M. (2017). The gender wage gap: Extent, trends, and explanations. Journal of Economic Literature, 55(3):789-865. 
Card, D., Cardoso, A. R., Heining, J., and Kline, P. (2018). Firms and labor market inequality: Evidence and some theory. Journal of Labor Economics, 36(S1):S13S70.

Card, D., Cardoso, A. R., Kline, P., et al. (2016). Bargaining, sorting, and the gender wage gap: Quantifying the impact of firms on the relative pay of women. The Quarterly Journal of Economics, 131(2):633-686.

Card, D., Devicienti, F., and Maida, A. (2013). Rent-sharing, holdup, and wages: Evidence from matched panel data. Review of Economic Studies, 81(1):84-111.

Cardoso, A. R. and Winter-Ebmer, R. (2010). Female-led firms and gender wage policies. ILR Review, 64(1):143-163.

Cho, D. (2018). The labor market effects of demand shocks: Firm-level evidence from the recovery act. Working paper.

Ferraz, C., Finan, F., and Szerman, D. (2015). Procuring firm growth: The effects of government purchases on firm dynamics. Working Paper 21219, National Bureau of Economic Research.

Ferreira, F. H., Velez, C. E., and Paes de Barros, R. (2004). Inequality and Economic Development in Brazil. The World Bank.

Flabbi, L., Macis, M., Moro, A., and Schivardi, F. (2016). Do female executives make a difference? the impact of female leadership on gender gaps and firm performance. Technical report, National Bureau of Economic Research.

Fraga, E., Gonzaga, G., and Soares, R. R. (2017). Selection on ability and the early career growth in the gender wage gap.

Gagliarducci, S., Paserman, M. D., et al. (2015). The effect of female leadership on establishment and employee outcomes: Evidence from linked employer-employee data. Research in Labor Economics, 41:343-375.

Goldin, C. (2006). The quiet revolution that transformed women's employment, education, and family. American economic review, 96(2):1-21.

Goldin, C. (2014). A grand gender convergence: Its last chapter. American Economic Review, 104(4):1091-1119.

Goldin, C. and Katz, L. F. (2016). A most egalitarian profession: pharmacy and the evolution of a family-friendly occupation. Journal of Labor Economics, 34(3):705-746. 
Goldin, C., Kerr, S. P., Olivetti, C., and Barth, E. (2017). The expanding gender earnings gap: Evidence from the lehd-2000 census. American Economic Review, 107(5):110-14.

Hardy, M. and Kagy, G. (2018). Mind the (profit) gap: Why are female enterprise owners earning less than men? AEA Papers and Proceedings, 108:252-55.

Helpman, E., Itskhoki, O., Muendler, M.-A., and Redding, S. J. (2017). Trade and inequality: From theory to estimation. The Review of Economic Studies, 84(1):357-405.

Hildreth, A. K. (1998). Rent-sharing and wages: product demand or technology driven premia? Economics of Innovation and New Technology, 5(2-4):199-226.

Kline, P., Petkova, N., Williams, H., and Zidar, O. (2018). Who profits from patents? rent-sharing at innovative firms. Working Paper 25245, National Bureau of Economic Research.

Lopes de Melo, R. (2018). Firm wage differentials and labor market sorting: Reconciling theory and evidence. Journal of Political Economy, 126(1):313346.

Macis, M. and Schivardi, F. (2016). Exports and wages: Rent sharing, workforce composition, or returns to skills? Journal of Labor Economics, 34(4):945-978.

Madalozzo, R. (2010). Occupational segregation and the gender wage gap in Brazil: an empirical analysis. Economia aplicada, 14(2):147-168.

Martins, P. S. and Esteves, L. A. (2006). Is there rent sharing in developing countries? matched-panel evidence from brazil.

Menezes-Filho, N. A., Muendler, M.-A., and Ramey, G. (2008). The structure of worker compensation in Brazil, with a comparison to france and the united states. The Review of Economics and Statistics, 90(2):324-346.

Nekby, L. (2003). Gender differences in rent sharing and its implications for the gender wage gap, evidence from sweden. Economics Letters, 81(3):403 - 410.

Salardi, P. (2012). Wage disparities and occupational intensity by gender and race in brazil: An empirical analysis using quantile decomposition techniques.

Song, J., Price, D. J., Guvenen, F., Bloom, N., and Von Wachter, T. (2015). Firming up inequality. Technical report, National Bureau of Economic Research.

Szerman, D. (2012). Public procurement auctions in Brazil. PhD thesis, The London School of Economics and Political Science (LSE). 
Van Reenen, J. (1996). The creation and capture of rents: wages and innovation in a panel of uk companies. The Quarterly Journal of Economics, 111(1):195-226.

World Bank, T. (2004). Brazil: Country procurement assessment report. Technical report, World Bank. 
Table 1: Summary statistics at the firm level

\begin{tabular}{lccc}
\hline \hline & $(1)$ & $(2)$ & $(3)$ \\
& Mean & Std. Dev. & $\mathrm{N}$ \\
\hline \# of owners & 1.97 & 0.75 & 42,159 \\
\# of male owners & 1.21 & 0.85 & 42,159 \\
\# of female owners & 0.67 & 0.68 & 42,159 \\
\# of legal entity owners & 0.08 & 0.38 & 42,159 \\
Female-led firms & 0.17 & 0.37 & 41,002 \\
Male-led firms & 0.47 & 0.50 & 41,002 \\
Firms with legal entity owners & 0.06 & 0.23 & 42,159 \\
\hline
\end{tabular}

Notes: i) Information about owners was only available to 42,159 firms of 42,398 , ii) Within firms that had information about ownership, 1,157 firms had only legal entity owners and had no information about gender assigned, iii) Female led firms have majority of women owners and maleled firms have most owners male. 


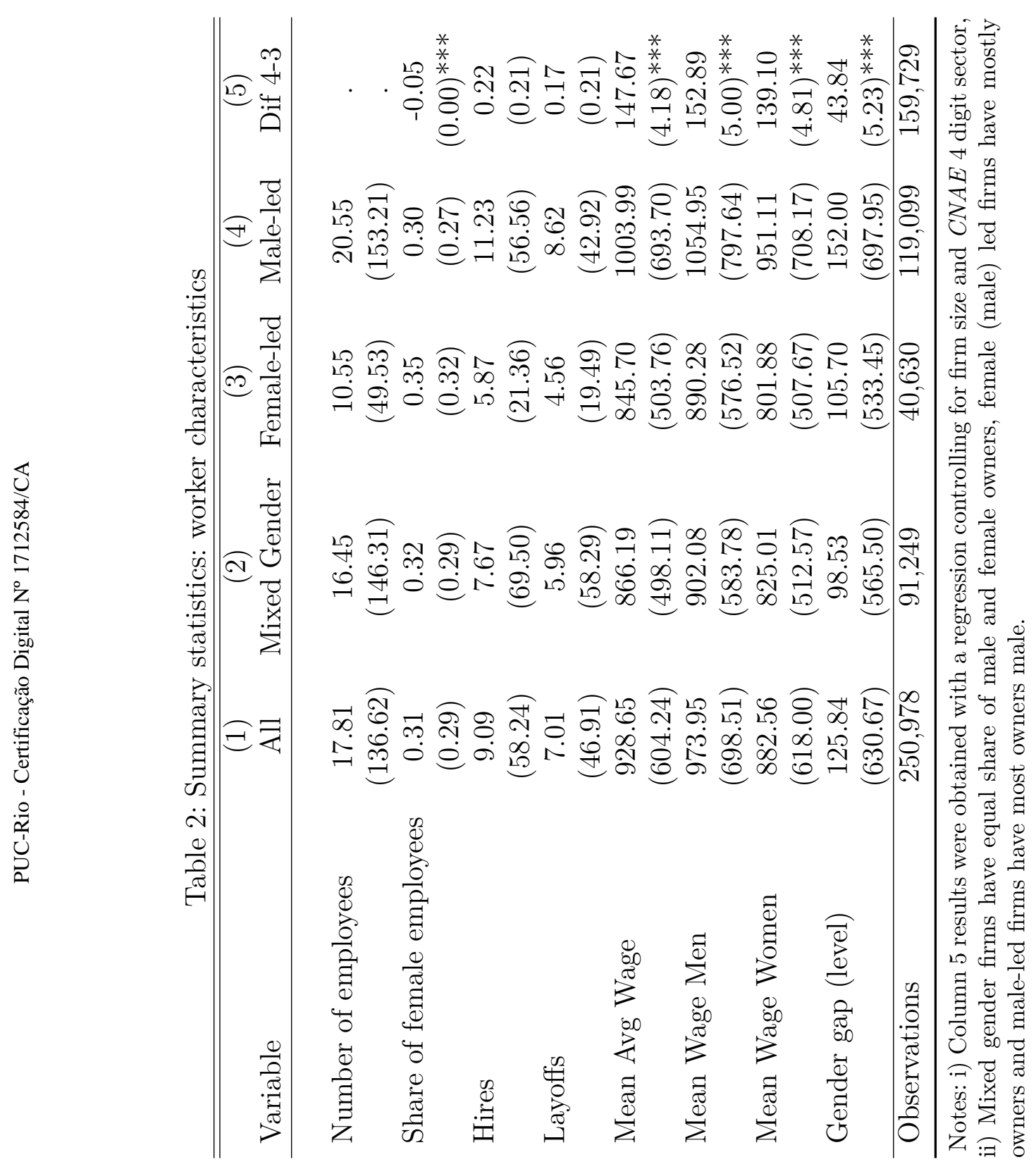


Table 3: Balance table: winners vs runner ups

\begin{tabular}{|c|c|c|c|}
\hline & $\begin{array}{c}(1) \\
\text { Winner }\end{array}$ & $\begin{array}{c}(2) \\
\text { Runner up }\end{array}$ & $\begin{array}{c}(3) \\
\text { P-value }\end{array}$ \\
\hline Number of employees & $\begin{array}{c}30.2 \\
(185.6)\end{array}$ & $\begin{array}{c}24.5 \\
(172.1)\end{array}$ & 0.036 \\
\hline \# of male employees & $\begin{array}{c}21.1 \\
(165.4)\end{array}$ & $\begin{array}{c}17.1 \\
(151.5)\end{array}$ & 0.067 \\
\hline \# of female employees & $\begin{array}{c}9.10 \\
(37.1)\end{array}$ & $\begin{array}{c}7.43 \\
(35.1)\end{array}$ & 0.020 \\
\hline Share of female workers & $\begin{array}{c}0.38 \\
(0.18)\end{array}$ & $\begin{array}{c}0.39 \\
(0.18)\end{array}$ & 0.48 \\
\hline Mean wage (log) & $\begin{array}{c}6.66 \\
(0.38)\end{array}$ & $\begin{array}{c}6.63 \\
(0.36)\end{array}$ & 0.16 \\
\hline Mean male wage (log) & $\begin{array}{c}6.67 \\
(0.41)\end{array}$ & $\begin{array}{c}6.64 \\
(0.39)\end{array}$ & 0.19 \\
\hline Mean female wage (log) & $\begin{array}{c}6.60 \\
(0.39)\end{array}$ & $\begin{array}{c}6.58 \\
(0.37)\end{array}$ & 0.29 \\
\hline Share of high skilled (HS) & $\begin{array}{c}0.63 \\
(0.28)\end{array}$ & $\begin{array}{c}0.63 \\
(0.28)\end{array}$ & 0.58 \\
\hline Share of female HS & $\begin{array}{c}0.29 \\
(0.19)\end{array}$ & $\begin{array}{c}0.29 \\
(0.19)\end{array}$ & 0.75 \\
\hline Share of male HS & $\begin{array}{c}0.35 \\
(0.23)\end{array}$ & $\begin{array}{c}0.34 \\
(0.23)\end{array}$ & 0.77 \\
\hline Mean Age & $\begin{array}{c}31.9 \\
(5.20)\end{array}$ & $\begin{array}{c}31.7 \\
(5.46)\end{array}$ & 0.38 \\
\hline
\end{tabular}

Notes: Table shows means and standard deviations of selected variables for winners and runner ups the year before the shock. P-value test for the null that the means are the same and are obtained from a regression with auction fixed effect, standard errors clustered at the firm level and conditional on past winning close auctions. Sample: 265,714 close auctions with 2 active bidders in last 30 seconds with bid difference smaller than 0.5 . 
Table 4: Correlation between instrument and predetermined variables

\begin{tabular}{|c|c|c|c|}
\hline Dependent Variable: $Z_{t}$ & $\begin{array}{c}(1) \\
t-1\end{array}$ & $\begin{array}{c}(2) \\
t-2\end{array}$ & $\begin{array}{c}(3) \\
\Delta_{t-1} \\
\end{array}$ \\
\hline Share high-skilled women & $\begin{array}{l}-0.041 \\
(0.078)\end{array}$ & $\begin{array}{l}-0.120 \\
(0.076)\end{array}$ & $\begin{array}{c}0.081 \\
(0.065)\end{array}$ \\
\hline Share high-skilled men & $\begin{array}{l}-0.044 \\
(0.046)\end{array}$ & $\begin{array}{c}-0.087^{*} \\
(0.051)\end{array}$ & $\begin{array}{c}0.025 \\
(0.041)\end{array}$ \\
\hline Avg age male workers & $\begin{array}{c}0.002 \\
(0.002)\end{array}$ & $\begin{array}{l}-0.001 \\
(0.002)\end{array}$ & $\begin{array}{c}0.002 \\
(0.002)\end{array}$ \\
\hline Avg age female workers & $\begin{array}{l}-0.000 \\
(0.002)\end{array}$ & $\begin{array}{l}-0.001 \\
(0.002)\end{array}$ & $\begin{array}{c}0.001 \\
(0.001)\end{array}$ \\
\hline Avg tenure women & $\begin{array}{l}-0.000 \\
(0.000)\end{array}$ & $\begin{array}{l}-0.001 \\
(0.000)\end{array}$ & $\begin{array}{c}0.001 \\
(0.000)\end{array}$ \\
\hline Avg tenure men & $\begin{array}{l}-0.000 \\
(0.001)\end{array}$ & $\begin{array}{l}-0.000 \\
(0.001)\end{array}$ & $\begin{array}{c}0.000 \\
(0.001)\end{array}$ \\
\hline Number of employees (log) & $\begin{array}{l}-0.010 \\
(0.090)\end{array}$ & $\begin{array}{c}0.054 \\
(0.084)\end{array}$ & $\begin{array}{c}0.012 \\
(0.071)\end{array}$ \\
\hline Male employees (log) & $\begin{array}{l}-0.044 \\
(0.110)\end{array}$ & $\begin{array}{l}-0.165 \\
(0.101)\end{array}$ & $\begin{array}{c}0.002 \\
(0.087)\end{array}$ \\
\hline Female employees (log) & $\begin{array}{l}-0.005 \\
(0.050)\end{array}$ & $\begin{array}{c}0.046 \\
(0.051)\end{array}$ & $\begin{array}{c}0.002 \\
(0.039)\end{array}$ \\
\hline Share of female workers & $\begin{array}{l}-0.084 \\
(0.341)\end{array}$ & $\begin{array}{l}-0.398 \\
(0.323)\end{array}$ & $\begin{array}{l}-0.067 \\
(0.270)\end{array}$ \\
\hline Avg wage & $\begin{array}{l}-0.000 \\
(0.000)\end{array}$ & $\begin{array}{c}-0.000^{*} \\
(0.000)\end{array}$ & $\begin{array}{c}0.000 \\
(0.000)\end{array}$ \\
\hline Avg wage men & $\begin{array}{l}-0.000 \\
(0.000)\end{array}$ & $\begin{array}{c}0.000 \\
(0.000)\end{array}$ & $\begin{array}{l}-0.000 \\
(0.000)\end{array}$ \\
\hline Avg wage women & $\begin{array}{l}0.000 * \\
(0.000)\end{array}$ & $\begin{array}{l}0.000^{*} \\
(0.000)\end{array}$ & $\begin{array}{l}-0.000 \\
(0.000)\end{array}$ \\
\hline Mean occup. rank men & $\begin{array}{l}-0.000 \\
(0.001)\end{array}$ & $\begin{array}{c}-0.002^{*} \\
(0.001)\end{array}$ & $\begin{array}{c}0.001 \\
(0.001)\end{array}$ \\
\hline Mean occup. rank women & $\begin{array}{l}0.001^{*} \\
(0.001)\end{array}$ & $\begin{array}{c}0.001 \\
(0.001)\end{array}$ & $\begin{array}{c}0.000 \\
(0.001)\end{array}$ \\
\hline Max occup. rank men & $\begin{array}{c}0.001 \\
(0.001)\end{array}$ & $\begin{array}{l}0.001^{*} \\
(0.001)\end{array}$ & $\begin{array}{l}-0.000 \\
(0.000)\end{array}$ \\
\hline Max occup. rank women & $\begin{array}{l}-0.001 \\
(0.001)\end{array}$ & $\begin{array}{l}-0.000 \\
(0.001)\end{array}$ & $\begin{array}{l}-0.000 \\
(0.000)\end{array}$ \\
\hline Observations & 12,840 & 11,255 & 11,128 \\
\hline R-squared & 0.007 & 0.009 & 0.002 \\
\hline Number of firms & 6,703 & 5,888 & 5,812 \\
\hline
\end{tabular}


Table 5: Effect of demand shock on hourly wages of stayers

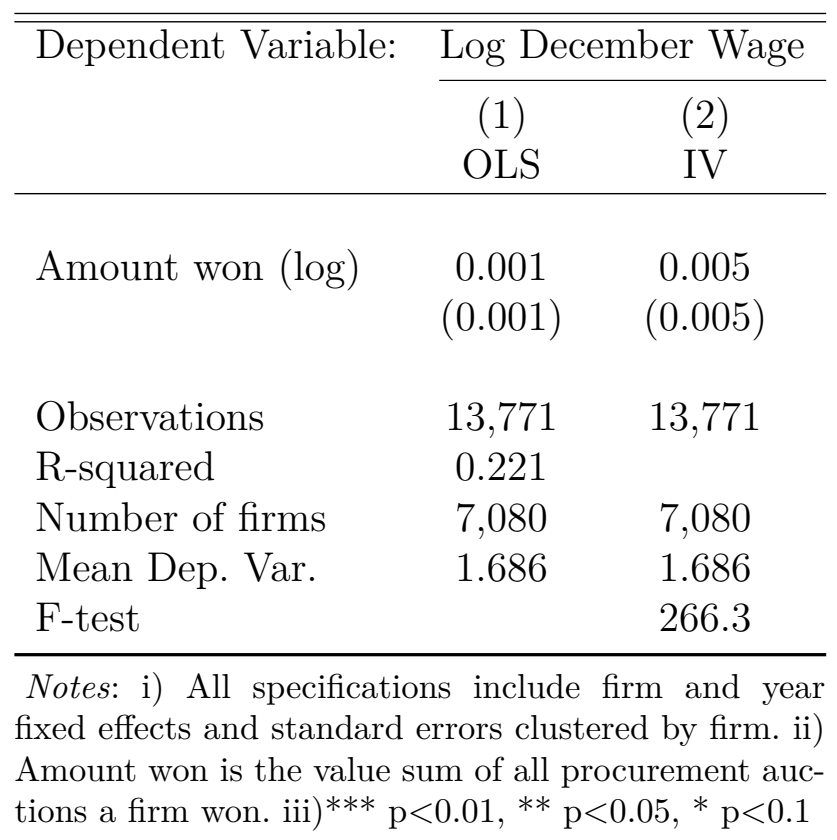


Table 6: Effect of demand shocks on wages by gender (IV)

Dependent Variable (log): Mean Wage Male Mean Wage Female

Amount won $(\log )$

0.005

0.001

$(0.006)$

(0.006)

Observations

13,771

13,771

Number of firms

7,080

7,080

Mean Dep. Var.

1.698

1.603

F-test

266.3

266.3

Notes: i) All specifications include firm and year fixed effects and standard errors clustered by firm. ii) Amount won is the value sum of all procurement auctions a firm won. iii)*** $\mathrm{p}<0.01,{ }^{* *} \mathrm{p}<0.05,{ }^{*} \mathrm{p}<0.1$ 
Table 7: Effect of demand shocks on wages by firm type (IV)

\begin{tabular}{|c|c|c|c|}
\hline \multirow[t]{2}{*}{ Dependent Variable (log): } & Mean Wage & Mean Wage Male & Mean Wage Female \\
\hline & $(1)$ & $(2)$ & $(3)$ \\
\hline \multirow[t]{2}{*}{ Amount won (log) } & 0.009 & 0.011 & 0.008 \\
\hline & $(0.008)$ & $(0.009)$ & $(0.009)$ \\
\hline \multirow[t]{2}{*}{ Amount won*Female-led } & -0.000 & 0.005 & -0.004 \\
\hline & $(0.014)$ & $(0.017)$ & $(0.017)$ \\
\hline \multirow[t]{2}{*}{ Amount won*Male-led } & -0.009 & -0.016 & 0.014 \\
\hline & $(0.011)$ & $(0.012)$ & $(0.013)$ \\
\hline Observations & 13,771 & 13,771 & 13,771 \\
\hline Number of firms & 7,080 & 7,080 & 7,080 \\
\hline Mean Dep. Var. & 1.686 & 1.698 & 1.603 \\
\hline F-test & 266.3 & 266.3 & 266.3 \\
\hline
\end{tabular}

Notes: i) All specifications include firm and year fixed effects and standard errors clustered by firm. ii) Amount won is the value sum of all procurement auctions a firm won. iii) ${ }^{* * *} \mathrm{p}<0.01,{ }^{* *} \mathrm{p}<0.05$, * $\mathrm{p}<0.1$ iv) Mixed gender firms have equal share of male and female owners, female-led have a greater share of women owners and male-led firms more male owner 
Table 8: Effect of demand shocks on intrafirm gender gap (IV)

\begin{tabular}{lc}
\hline \hline Dependent Variable: & Log Mean Wage \\
\cline { 2 - 2 } & $(1)$ \\
\hline & \\
Amount won (log) & -0.001 \\
& $(0.014)$ \\
Amount won*Female-led & 0.009 \\
& $(0.027)$ \\
Amount won*Male-led & -0.010 \\
& $(0.021)$ \\
Observations & 13,771 \\
Number of firms & 7,080 \\
Mean Dep. Var. & 0.0019 \\
F-test & 266.3 \\
\hline
\end{tabular}

Notes: i) All specifications include firm and year fixed effects and standard errors clustered by firm. ii) Amount won is the value sum of all procurement auctions a firm won. iii)*** $\mathrm{p}<0.01$, ** $\mathrm{p}<0.05$, * $\mathrm{p}<0.1$ iv) Mixed gender firms have equal share of male and female owners, female-led have a greater share of women owners and male-led firms more male owner 
Table 9: First stage

\begin{tabular}{lc}
\hline \hline Dependent Variable: & $(1)$ \\
\hline Share won in close auctions & $1.223^{* * *}$ \\
& $(0.075)$ \\
& \\
Observations & 13,771 \\
Number of firms & 7,080 \\
R-squared & 0.094 \\
F-test & 266.3 \\
\hline
\end{tabular}

Notes: All specifications include firm and year fixed effects and standard errors clustered by firm. 
Table 10: Effect of demand shock on mean wages of stayers by market share (IV)

\begin{tabular}{lcc}
\hline \hline Dependent Variable $(\log ):$ & \multicolumn{2}{c}{ December Wage } \\
\cline { 2 - 3 } & $\begin{array}{c}(1) \\
\text { Competitive market } \\
(\mathrm{HHI} \leq 0.15)\end{array}$ & $\begin{array}{c}\text { Concentrated market } \\
(\mathrm{HHI}>0.15)\end{array}$ \\
\hline Amount won $(\log )$ & 0.004 & 0.026 \\
& $(0.005)$ & $(0.022)$ \\
Observations & 12,539 & 1,232 \\
Number of firms & 6,601 & 746 \\
Mean Dep. Var. & 1.673 & 1.809 \\
F-test & 232.9 & 14.95
\end{tabular}

Notes: All specifications include firm and year fixed effects and standard errors clustered by firm. Amount won is the value sum of all procurement auctions a firm won. 
Table 11: Effect of demand shocks on wages by gender and market share (IV)

\begin{tabular}{lccccc}
\hline \hline & \multicolumn{2}{c}{ Competitive market } & & \multicolumn{2}{c}{ Concentrated market } \\
\cline { 2 - 3 } Dependent Variable: & $\begin{array}{c}\text { Wage Male } \\
(1)\end{array}$ & $\begin{array}{c}\text { Wage Female } \\
(2)\end{array}$ & & $\begin{array}{c}\text { Wage Male } \\
(3)\end{array}$ & $\begin{array}{c}\text { Wage Female } \\
(4)\end{array}$ \\
\hline \multirow{2}{*}{ Amount won (log) } & 0.004 & -0.001 & & 0.009 & $0.045^{* *}$ \\
& $(0.006)$ & $(0.006)$ & & $(0.025)$ & $(0.023)$ \\
& & & & 1,232 & 1,232 \\
Observations & 12,539 & 12,539 & & 746 & 746 \\
Number of firms & 6,601 & 6,601 & & 1.840 & 1.695 \\
Mean Dep. Var. & 1.664 & 1.594 & & 14.95 & 14.95 \\
F-test & 232.9 & 232.9 & &
\end{tabular}

Notes: i) All specifications include firm and year fixed effects and standard errors clustered by firm. ii) Amount won is the value sum of all procurement auctions a firm won. iii) ${ }^{* * *} \mathrm{p}<0.01$, ** $\mathrm{p}<0.05,{ }^{*} \mathrm{p}<0.1$ 
Table 12: Effect of demand shock on mean wages of stayers by education group (IV)

\begin{tabular}{lcc}
\hline \hline Dependent Variable $(\log ):$ & \multicolumn{2}{c}{ December Wage } \\
\cline { 2 - 3 } & $\begin{array}{c}(1) \\
\text { High skill }\end{array}$ & $\begin{array}{c}(2) \\
\text { Low skill }\end{array}$ \\
\hline Amount won (log) & 0.003 & 0.006 \\
& $(0.006)$ & $(0.006)$ \\
Observations & 13,132 & 10,695 \\
Number of firms & 7,012 & 149 \\
Mean Dep. Var. & 1.734 & 1.536 \\
F-test & 250.1 & 222.9 \\
\hline
\end{tabular}

Notes: i) All specifications include firm and year fixed effects and standard errors clustered by firm. ii) Amount won is the value sum of all procurement auctions a firm won. iii)*** $\mathrm{p}<0.01,{ }^{* *} \mathrm{p}<0.05,{ }^{*} \mathrm{p}<0.1$ 
Table 13: Effect of demand shocks on wages by gender and education group (IV)

\begin{tabular}{lccccc}
\hline \hline & \multicolumn{2}{c}{ High skill } & & \multicolumn{2}{c}{ Low skill } \\
\cline { 6 - 6 } \cline { 5 - 6 } Dependent Variable $(\log ):$ & $\begin{array}{c}(1) \\
\text { Wage Male }\end{array}$ & $\begin{array}{c}(2) \\
\text { Wage Female }\end{array}$ & $\begin{array}{c}(3) \\
\text { Wage Male }\end{array}$ & $\begin{array}{c}(4) \\
\text { Wage Female }\end{array}$ \\
\hline Amount won (log) & 0.009 & -0.005 & & 0.005 & 0.008 \\
& $(0.007)$ & $(0.007)$ & & $(0.006)$ & $(0.007)$ \\
Observations & & & & & \\
Number of firms & 12,012 & 12,255 & & 9,779 & 6,517 \\
Mean Dep. Var. & 6,352 & 6,435 & & 5,154 & 3,525 \\
F-test & 1.776 & 1.657 & & 1.571 & 1.414 \\
\hline
\end{tabular}

Notes: i) All specifications include firm and year fixed effects and standard errors clustered by firm. ii) Amount won is the value sum of all procurement auctions a firm won. iii) ${ }^{* * *} \mathrm{p}<0.01,{ }^{* *} \mathrm{p}<0.05$, $^{*}$ $\mathrm{p}<0.1$ 
Table 14: Effect of demand shocks on wages by firm type and education (IV)

\begin{tabular}{lcc}
\hline \hline Dependent Variable (log): & \multicolumn{2}{c}{ December mean wage } \\
\cline { 2 - 3 } & $\begin{array}{c}(1) \\
\text { High skill }\end{array}$ & $\begin{array}{c}(2) \\
\text { Low skill }\end{array}$ \\
\hline \multirow{2}{*}{ Amount won $(\log )$} & 0.014 & 0.005 \\
& $(0.010)$ & $(0.008)$ \\
Amount won*Female-led & -0.009 & 0.017 \\
& $(0.017)$ & $(0.016)$ \\
Amount won*Male-led & -0.021 & -0.005 \\
& $(0.013)$ & $(0.012)$ \\
Observations & & \\
Number of firms & 13,132 & 10,695 \\
Mean Dep. Var. & 6,819 & 5,600 \\
F-test & 1.734 & 1.536 \\
& 250.1 & 222.9 \\
\hline
\end{tabular}

Notes: i) All specifications include firm and year fixed effects and standard errors clustered by firm. ii) Amount won is the value sum of all procurement auctions a firm won. iii) ${ }^{* * *}$ $\mathrm{p}<0.01,{ }^{* *} \mathrm{p}<0.05, * \mathrm{p}<0.1$ iv) Mixed gender firms have equal share of male and female owners, female-led have a greater share of women owners and male-led firms more male owner 
Table 15: Effect of demand shock on mean wages of stayers by firm size (IV)

\begin{tabular}{lcc}
\hline \hline Dependent Variable $(\log ):$ & \multicolumn{2}{c}{ December Wage } \\
\cline { 2 - 3 } & Below median size & Above median size \\
\hline \multirow{2}{*}{ Amount won (log) } & 0.012 & -0.000 \\
& $(0.009)$ & $(0.005)$ \\
Observations & & \\
Number of firms & 6,571 & 7,200 \\
Mean Dep. Var. & 3,664 & 3,416 \\
F-test & 1.588 & 1.775 \\
\hline
\end{tabular}

Notes: i) All specifications include firm and year fixed effects and standard errors clustered by firm. ii) Amount won is the value sum of all procurement auctions a firm won. iii) ${ }^{* * *} \mathrm{p}<0.01,{ }^{* *} \mathrm{p}<0.05,{ }^{*} \mathrm{p}<0.1$ 
Table 16: Effect of demand shocks on wages by gender and firm size (IV)

\begin{tabular}{|c|c|c|c|c|}
\hline \multirow[b]{2}{*}{ Dependent Variable (log): } & \multicolumn{2}{|c|}{ Below median size } & \multicolumn{2}{|c|}{ Above median size } \\
\hline & $\begin{array}{c}(1) \\
\text { Wage Male } \\
\end{array}$ & $\begin{array}{c}(2) \\
\text { Wage Female } \\
\end{array}$ & $\begin{array}{c}(3) \\
\text { Wage Male } \\
\end{array}$ & $\begin{array}{c}(4) \\
\text { Wage Female } \\
\end{array}$ \\
\hline Amount won (log) & $\begin{array}{c}0.002 \\
(0.011)\end{array}$ & $\begin{array}{c}0.011 \\
(0.011)\end{array}$ & $\begin{array}{c}0.005 \\
(0.006)\end{array}$ & $\begin{array}{l}-0.005 \\
(0.007)\end{array}$ \\
\hline Observations & 6,571 & 6,571 & 7,200 & 7,200 \\
\hline Number of firms & 6,664 & 6,664 & 5,416 & 3,416 \\
\hline Mean Dep. Var. & 1.587 & 1.522 & 1.799 & 1.676 \\
\hline F-test & 90.41 & 90.41 & 176 & 176 \\
\hline
\end{tabular}

Notes: i) All specifications include firm and year fixed effects and standard errors clustered by firm. ii) Amount won is the value sum of all procurement auctions a firm won. iii) ${ }^{* * *} \mathrm{p}<0.01,{ }^{* *} \mathrm{p}<0.05$, $^{*}$ $\mathrm{p}<0.1$ 
Table 17: Effect of demand shocks on wages by firm type and size (IV)

\begin{tabular}{lcc}
\hline \hline Dependent Variable $(\log ):$ & \multicolumn{2}{c}{ December wage } \\
\cline { 2 - 3 } & Below median size & Above median size \\
\hline
\end{tabular}

$\begin{array}{lcc}\text { Amount won (log) } & 0.024 & -0.000 \\ & (0.016) & (0.008) \\ \text { Amount won*Female-led } & -0.010 & 0.003 \\ & (0.025) & (0.017) \\ \text { Amount won*Male-led } & -0.026 & -0.005 \\ & (0.021) & (0.012) \\ & & 7,200 \\ \text { Observations } & 6,571 & 5,416 \\ \text { Number of firms } & 6,664 & 1.775 \\ \text { Mean Dep. Var. } & 1.588 & 176 \\ \text { F-test } & 90.41 & \end{array}$

Notes: i) All specifications include firm and year fixed effects and standard errors clustered by firm. ii) Amount won is the value sum of all procurement auctions a firm won. iii) $\left.{ }^{* * *} \mathrm{p}<0.01,{ }^{* *} \mathrm{p}<0.05,{ }^{*} \mathrm{p}<0.1 \mathrm{iv}\right)$ Mixed gender firms have equal share of male and female owners, female-led have a greater share of women owners and male-led firms more male owner 


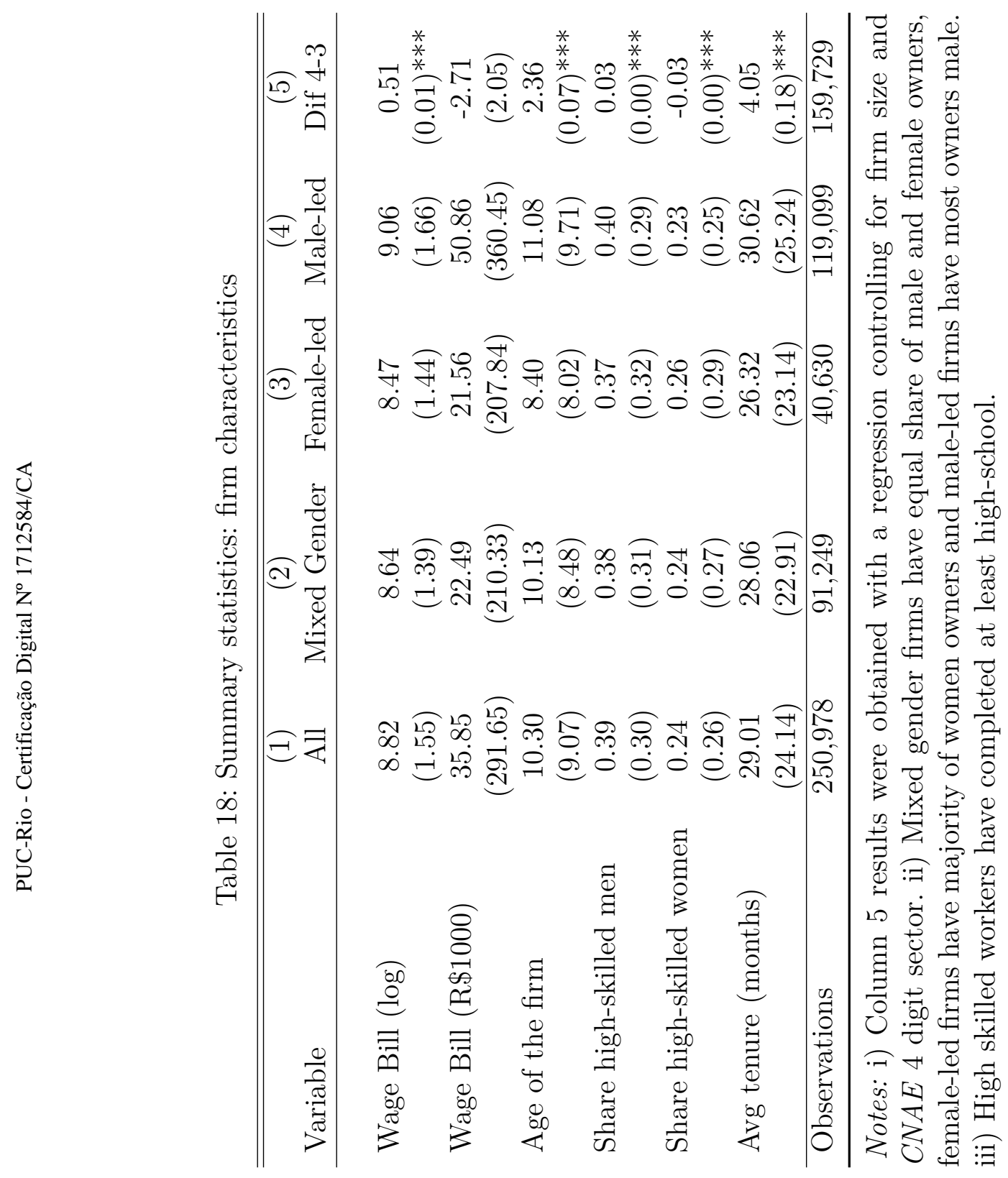




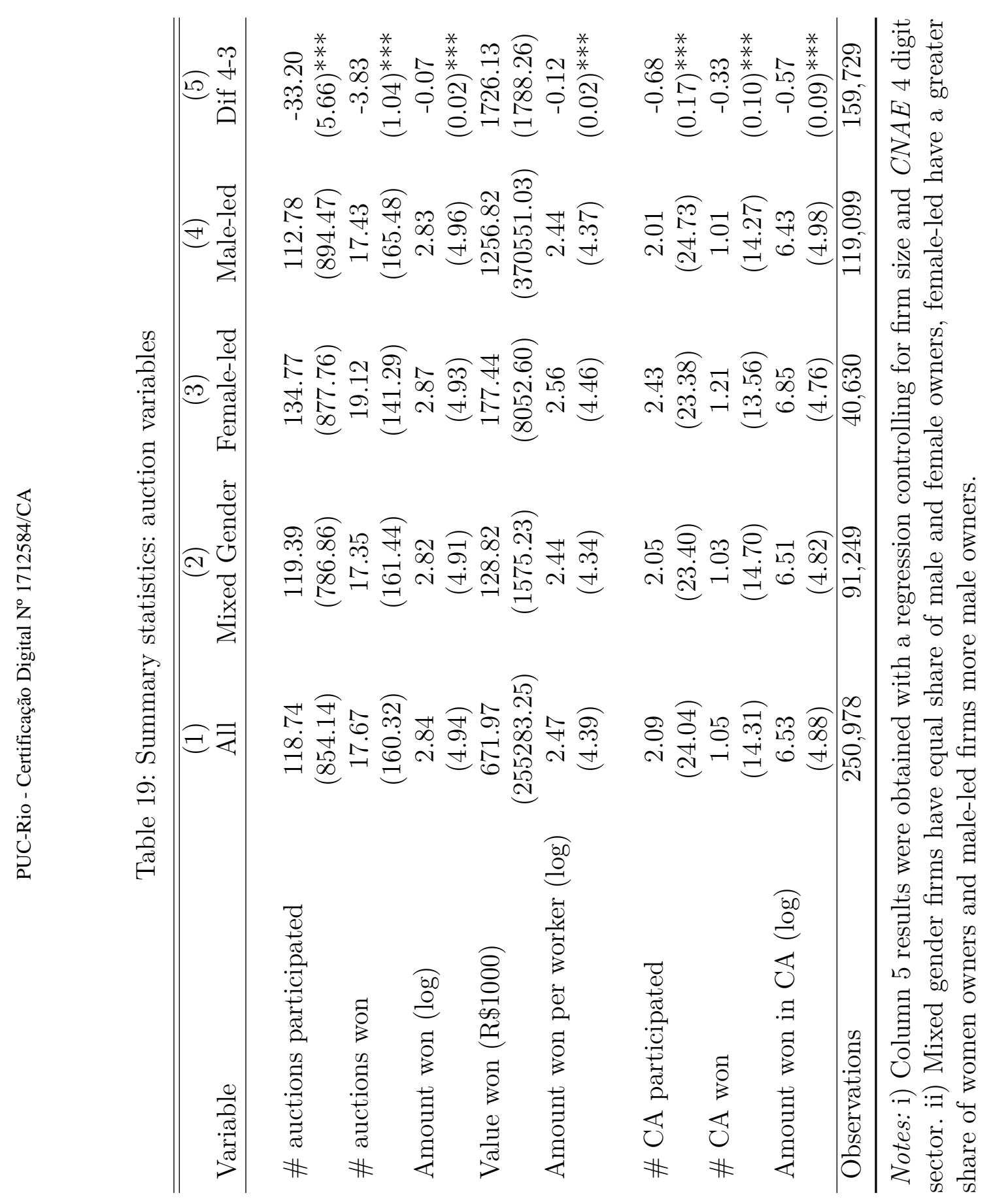


Table 20: Effect of demand shocks on different measures of wages (IV)

\begin{tabular}{lccccc}
\hline \hline Dependent Variable $(\log )$ & \multicolumn{2}{c}{ Average Wage } & & \multicolumn{2}{c}{ December Wage } \\
\cline { 2 - 3 } & $\begin{array}{c}(1) \\
\text { All workers }\end{array}$ & $\begin{array}{c}(2) \\
\text { Stayers }\end{array}$ & & $\begin{array}{c}(3) \\
\text { All workers }\end{array}$ & $\begin{array}{c}(4) \\
\text { Stayers }\end{array}$ \\
\hline \multirow{2}{*}{ Amount won (log) } & -0.002 & -0.003 & & 0.004 & 0.005 \\
& $(0.004)$ & $(0.004)$ & & $(0.004)$ & $(0.004)$ \\
& & & & & \\
Observations & 13,771 & 13,771 & & 13,771 & 13,771 \\
Number of firms & 7,080 & 7,080 & & 7,080 & 7,080 \\
Mean Dep. Var. & 6.775 & 6.803 & & 6.820 & 6.840 \\
F-test & 266.3 & 266.3 & & 266.3 & 266.3 \\
\hline
\end{tabular}

Notes: i) All specifications include firm and year fixed effects and standard errors clustered by firm. ii) Amount won is the value sum of all procurement auctions a firm won. iii) ${ }^{* * *} \mathrm{p}<0.01,{ }^{* *} \mathrm{p}<0.05,{ }^{*} \mathrm{p}<0.1$ 
Table 21: Effect of demand shocks on next year wages

\begin{tabular}{lccccc}
\hline \hline \multirow{2}{*}{ Dependent Variable: } & \multicolumn{2}{c}{ Wages in T } & & \multicolumn{2}{c}{ Wages in T+1 } \\
\cline { 2 - 3 } & $\begin{array}{c}\text { OLS } \\
(1)\end{array}$ & $\begin{array}{c}\text { IV } \\
(2)\end{array}$ & & $\begin{array}{c}\text { OLS } \\
(3)\end{array}$ & $\begin{array}{c}\text { IV } \\
(4)\end{array}$ \\
\hline Amount won $(\log )$ & 0.001 & 0.005 & & 0.002 & 0.000 \\
& $(0.001)$ & $(0.005)$ & & $(0.001)$ & $(0.005)$ \\
& & & & \\
Observations & 13,771 & 13,771 & & 12,871 & 12,871 \\
R-squared & 0.221 & & 0.233 & \\
Number of firms & 7,080 & 7,080 & 6,778 & 6,778 \\
Mean Dep. Var. & 1.686 & 1.686 & & 1.743 & 1.743 \\
F-test & & 266.3 & & 239.5 \\
\hline
\end{tabular}

Notes: i) All specifications include firm and year fixed effects and standard errors clustered by firm. ii) Amount won is the value sum of all procurement auctions a firm won. iii) ${ }^{* * *} \mathrm{p}<0.01,{ }^{* *} \mathrm{p}<0.05$, * $\mathrm{p}<0.1$ 
Table 22: Effect of demand shock on mean wages of stayers by market share (hires)

\begin{tabular}{lcc}
\hline \hline Dependent Variable $(\log ):$ & \multicolumn{2}{c}{ December Wage } \\
\cline { 2 - 3 } & $\begin{array}{c}(1) \\
\text { Competitive market } \\
(\mathrm{HHI} \leq 0.15)\end{array}$ & $\begin{array}{c}\text { Concentrated market } \\
(\mathrm{HHI}>0.15)\end{array}$ \\
\hline Amount won $(\log )$ & 0.004 & -0.003 \\
& $(0.005)$ & $(0.015)$ \\
Observations & 12,788 & 983 \\
Number of firms & 6,694 & 618 \\
Mean Dep. Var. & 1.677 & 1.790 \\
F-test & 240.6 & 15.27 \\
\hline
\end{tabular}

Notes: i) All specifications include firm and year fixed effects and standard errors clustered by firm. ii) Amount won is the value sum of all procurement auctions a firm won. iii) ${ }^{* * *} \mathrm{p}<0.01,{ }^{* *} \mathrm{p}<0.05,{ }^{*} \mathrm{p}<0.1$ 